Comparison of the Enzyme-Linked Oligonucleotide Sorbent Assay to the ${ }^{32} \mathrm{p}$. labeled PCR/ Southern Blotting Technique in Quantitative Analysis of Human and Rat MRNA

Joseph A. Carcillo, 1,2 Robert A. Parise, ${ }^{2}$ and Marjorie Romkes-Sparks ${ }^{2,3}$

${ }^{1}$ Department of Anesthesiology and Critical Care Medicine, ${ }^{2}$ Center for Clinical Pharmacology, and ${ }^{3}$ Center for Environmental and Occupational Health and Toxicology, University of Pittsburgh, Pittsburgh, Pennsylvania 15261
The quantitation of mRNA expression has the potential to be of critical value in a clinical setting but, to date, has been limited by current quantitative PCR techniques. Many techniques evaluate the relative differences in target amounts rather than determine the copy number, and there are safety and time concerns associated with ${ }^{32} \mathrm{P}$ labeling of PCR products. The recently developed fluorescein-antifluorescein-based enzyme-linked oligonucleotide sorbent assay (FAF-ELOSA) technique overcomes many of these difficulties. We describe a comparison of results obtained by the ${ }^{32}$ P-labeled PCR/Southern blotting technique to the FAF-ELOSA. Key features of the FAF-ELOSA technique include quantitation by nonradioactive detection based on relative amounts of PCR product and a synthesized standard target. It is reproducible from a single cDNA preparation or from samples derived from separate preparations. The technique can easily be applied to clinical samples for the rapid determination of many different specific mRNA expression studies. We are currently applying this technique for the detection of CYP450 mRNA expression in a variety of human tissues from control and cancer patient populations.

Since the PCR method was first introduced in $1985,{ }^{(1)}$ the combination of reverse transcription (RT) with PCR (RTPCR) has increasingly been utilized to study gene expression. ${ }^{(2-5)}$ However, the use of mRNA quantitation as a clinical tool has been hampered by several limitations of currently utilized techniques, including the ${ }^{32} \mathrm{P}$-labeled PCR/Southern blotting technique. First, the ${ }^{32} \mathrm{P}$-labeled technique is considered semi-quantitative rather than quantitative because of the narrow linear range of film exposure and scanning densitometry. Also, the use of ${ }^{32} \mathrm{P}$ precludes automated mass analysis of clinical samples. Third, the quantitation of the target mRNA is dependent on the accuracy of the initial RNA quantitation and the relative efficiency of the RT. Finally, the blotting technique requires time periods that are not compatible with same day, diagnosis-directed therapeutic interventions.

In addition to varying cycle number, using amplification of a control gene in parallel, or using a competitive template as an internal control, ${ }^{(6)}$ several investigators have developed biotin, fluorescein, and streptavidin techniques to ad- dress these shortcomings. Syvanen et al. ${ }^{(7)}$ hybridized biotinylated PCR products to an oligonucleotide probe and immobilized the complex to avidin-coated beads. Saiki et al. ${ }^{(1)}$ showed that a PCR product could be identified specifically by hybridization to an oligonucleotide probe immobilized on a nylon membrane. The same principle has been applied to microtiter plate technology using ELOSA by Inouye and Hondo ${ }^{(8)}$ and Keller et al. ${ }^{(9,10)}$ Recently it was demonstrated that a double-stranded PCR product obtained with a biotinylated primer and a fluorescein-labeled primer could be detected upon immobilization in an avidin-coated plate and conjugation with a FAF-ELOSA. ${ }^{(11)}$ This technique has been successfully used to measure drug resistance of human immunodeficiency virus type 1 (HIV-1) isolates by determining relative HIV-1 copy number in the supernatant of cultured peripheral blood monocytes. ${ }^{(12)}$

To our knowledge, none of these studies have used the FAF-ELOSA protocol to quantitate mRNA, nor have they compared this quantitation with standard ${ }^{32} \mathrm{P}$ methodology. There have been reports that ${ }^{32} \mathrm{P}$ incorporation into the PCR product shows a good correlation with slot blot ${ }^{(3)}$ and Northern blot ${ }^{(4)}$ for the quantitation of the multidrug resistance gene $m d r-1$ expression and with in situ hybridization for progesterone receptor mRNA. ${ }^{(13)}$ In the present work we compare the relative sensitivity of the FAF-ELOSA with the sensitivity of the ${ }^{32}$ P-labeled PCR/Southern blotting technique in quantitation of PCR products used to measure rat and human actin mRNA. Cytochrome P450 CYP2D6 and CYP2E1 mRNA expression in human hepatic tissue are evaluated as an example of applying this technique to the analysis of specific mRNAs of interest in clinical samples.

\section{MATERIALS AND METHODS \\ Primer and Standard DNA Sequences}

The MacVector 4.1 (Kodak International Biotechnologies, Inc.) software package was used to select oligonucleotide and standard sequences. The nucleotide sequences of the primers selected for amplification of $\beta$-actin in rat (Table 1 ) and $\beta$-actin, CYP2D6, and CYP2E1 in human samples (Tables 1 and 2) are presented. 
TABLE 1 Oligonucleotide Primers and Probes for Human and Rat $\beta$-actin

\begin{tabular}{ll}
\hline Primer & Sequence \\
\hline Rat capture (ract.774Fb) & GAGGCTCTCT TCCAGCCT T \\
Rat reporter (ract.827Rf) & TCATGGATGCCACAGGAT TCC \\
Rat 5' primer (ract.612F) & TGAGAGGGAAATCGTGCGT \\
Rat synthetic target & ATCGGCAATGAGCGGTTCCGATGCCCCGAGGCTCTCTTCCAGCCTTCC \\
& TTCCTGGGTATGGAATCCTGTGGCATCCATGA \\
Human capture (hact.intFb) & GACAGGATGCAGAAGGAGAT \\
Human reporter (hact.1013Rf) & ATGATCT TGATCT TCATTGT \\
Human 5' primer (hact.874F) & AAACTACCTTCAACTCCATC \\
Human synthetic target & CCATGTACCCTGGCATTGCCGACAGGATGCAGAAGGAGATCACTGCC \\
& CTGGCACCCAGCACAATGAAGATCAAGGATCAT \\
\hline
\end{tabular}

The capture probes for the PCR product are listed, whereas the capture probes for the standards are the reverse complement. The $3^{\prime}$ primer for human actin is a splice-junction-specific primer designed to avoid the amplification of any contaminating genomic DNA. The standard oligonucleotides for both human and rat $\beta$-actin were synthesized to span the last $80 \mathrm{bp}$ of the expected target PCR product sequence, including the $3^{\prime}$ primer. Biotin and fluorescein 5 '-end labels were incorporated during oligonucleotide synthesis. The biotin-labeled primers were HPLC purified and the fluoresceinlabeled, and standard oligonucleotides were purified on NAP-5 columns (Pharmacia) (refer to Fig. 1).

\section{Tissue Collection and Total RNA Isolation}

For inactivation of RNases, all solutions were treated for at least $12 \mathrm{hr}$ with $0.1 \%$ (by volume) aqueous diethyl pyrocarbonate solution. A human liver sample and a rat heart ventricle sample were frozen at $-80^{\circ} \mathrm{C}$ until total RNA was isolated by the guanidinium thiocyanate phenol-chloroform single-step extrac- tion method using an RNA isolation kit (Stratagene, La Jolla, CA). The purity and quantity of the total RNA was determined spectrophotometrically (Shimadzu UV-2101 PC UV-Vis scanning spectrophotometer). The RNA preparation was treated with RNase-free DNase I (Stratagene Cloning Systems) to digest any contaminating genomic DNA.

\section{RT of Total RNA to CDNA}

Total RNA was reverse transcribed and the cDNA product amplified. Briefly, 1 $\mu \mathrm{g}$ of total RNA was mixed with $0.5 \mu \mathrm{l}$ of RNasin RNase inhibitor (40 $\mathrm{U} / \mu \mathrm{l})$ (Promega) and random hexamers (2.5 $\mu \mathrm{M})$ in a total volume of $9.5 \mu \mathrm{l}$. The mixture was heated to $94^{\circ} \mathrm{C}$ for $2 \mathrm{~min}$ and cooled on ice for $5 \mathrm{~min}$. To this mixture, a final concentration of RT buffer (1X), dithiothreitol $(0.01 \mathrm{M})$, and dNTP mix (1 $\mathrm{mm}$ ) was added to a total volume of 20 $\mu 1$. The mixture was incubated at $41^{\circ} \mathrm{C}$ for $15 \mathrm{~min}$, and $2 \mu \mathrm{l}$ of Superscript RNase $\mathrm{H}^{-}$RT enzyme (200 U/ $\left.\mu \mathrm{l}\right)$; (GIBCO-BRL) was added and incubated for an additional $60 \mathrm{~min}$ at $41^{\circ} \mathrm{C}$. The mixture was heated to $99^{\circ} \mathrm{C}$ for $5 \mathrm{~min}$ to inactivate the RT and cooled to $4^{\circ} \mathrm{C}$.

\section{${ }^{32} \mathrm{P}$ End-labeling of the 5 oligonucleotide}

The $5^{\prime}$ oligonucleotide was end-labeled with [ $\left.{ }^{32} \mathrm{P}\right]$ ATP with T4 polynucleotide kinase (U.S. Biochemical) by standard techniques. ${ }^{(14)}$

\section{PCR Amplification of CDNA}

To $1 \mu \mathrm{l}$ of the cDNA product, a final concentration of $1 \times$ PCR buffer [ $50 \mathrm{mM} \mathrm{KCl}$, $10 \mathrm{~mm}$ Tris- $\mathrm{HCl}$, (pH 8.3)]; $1 \mathrm{~mm} \mathrm{MgCl}_{2}$; $0.2 \mathrm{~mm}$ each of dATP, dCTP, dGTP, and dTTP; fluorescein-labeled 3 ' primer $(0.25$ $\mu \mathrm{M})$; unlabeled $5^{\prime}$ primer $(0.25 \mu \mathrm{M})$; and 2.5 units of AmpliTaq DNA polymerase (Perkin Elmer Cetus) was added. The final reaction volume was $100 \mu l$ (refer to Fig. 1). For the ${ }^{32} \mathrm{P}$-labeled PCR/Southern blotting technique, $10^{6} \mathrm{cpm}$ of ${ }^{32} \mathrm{P}$ endlabeled 5' primer was also added. The solution was overlaid with mineral oil and heated at $94^{\circ} \mathrm{C}$ for $5 \mathrm{~min}$ before the addition of AmpliTaq. The rat actin cDNA was amplified under the following conditions: $94^{\circ} \mathrm{C}$ for $1 \mathrm{~min}, 57^{\circ} \mathrm{C}$ for $1 \mathrm{~min}$, and $72^{\circ} \mathrm{C}$ for $3 \mathrm{~min}$, for up to 40 cycles. The human actin cDNA was amplified under similar conditions, except the an-

TABLE 2 Oligonucleotide Primers and Probes for Human CYP2D6 and CYP2E1

\begin{tabular}{ll}
\hline Primer & Sequence \\
\hline CYP2D6 capture (2D6.148Fb) & TGGGCAACCTGCTGCATGTG \\
CYP2D6 reporter (2D6.170Rf) & GGTCGAAGCAGTATGGTGTG \\
CYP2D6 5' primer (2D6.ATG) & ATGGGGCTAGAAGCACTGGT \\
CYP2D6 synthetic target & CCCACCAGGCCCCCTGCACTGCCCGGGCTGGGCAACCTGCTGCATG \\
& TGGACTTCCAGAACACACCATACTGCTTCGACC \\
CYP2E1 capture (2E1.67Fb) & TGGAGGCAGGTGCACAGCAG \\
CYP2E1 reporter (2E2.160Rf) & TGGGAAGCGGGAAAGGGCCT \\
CYP2E1 5' primer (2E1.ATG) & ATGTCTGCCCTCGGAGTCAC \\
CYP2E1 synthetic target & GGCCTTCCTCCTGCTGGTGTCCATGTGGAGGCAGGTGCACAGCAGCT \\
& GGAATCTGCCCCCAGGCCCTTTCCCGCTTCCCA \\
\hline
\end{tabular}



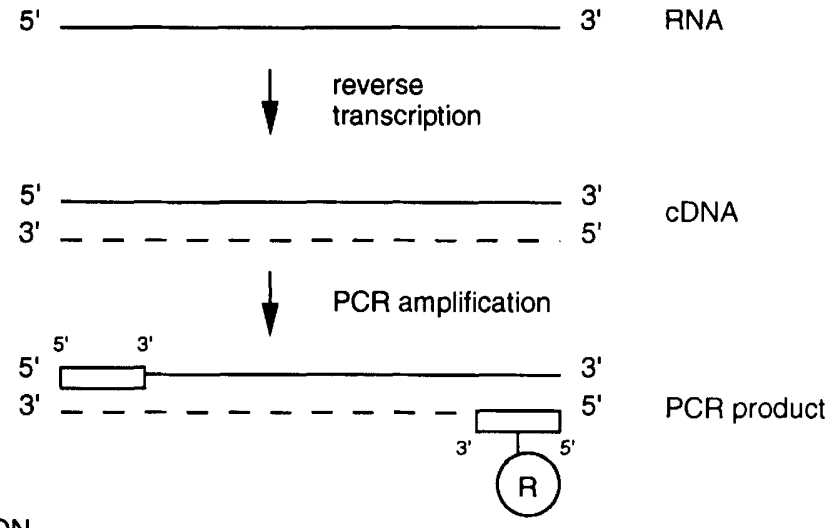

\section{ELOSA DETECTION}

PCR product

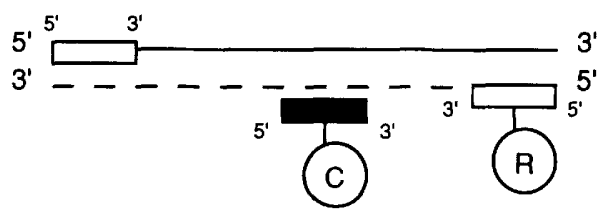

Standard

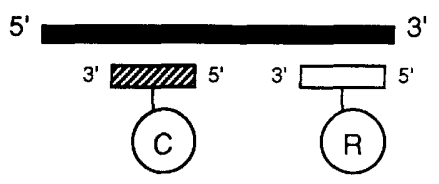

LEGEND

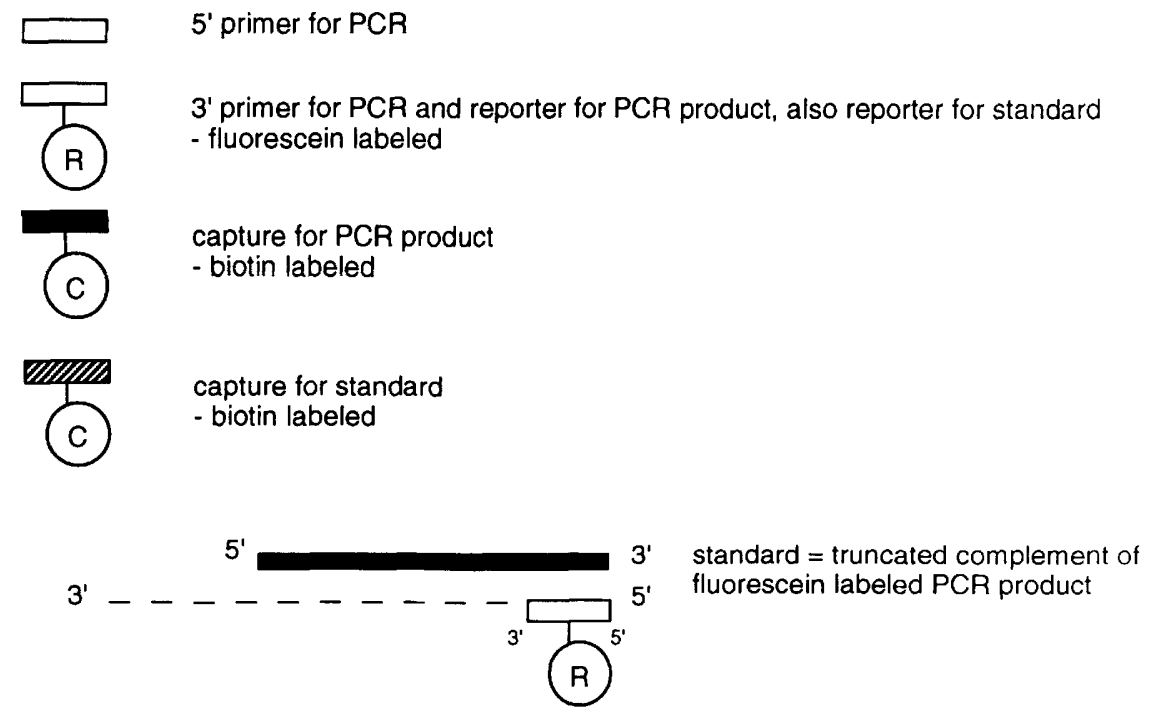

FICURE 1 FAF-ELOSA using 5'-fluorescein-labeled RT-PCR product and internal biotin capture probe, and standard DNA with fluorescein reporter probe and biotin capture probe.

nealing step was performed at $51^{\circ} \mathrm{C}$. PCR samples underwent agarose gel electrophoresis and sequencing to confirm the amplification of a single-band product. Control samples in which total RNA was not reverse transcribed and reaction mixture alone were also PCR amplified to verify that the reaction products were dependent on RT and not contaminated with extraneous DNA.

\section{Semiquantitative Analysis of 32P-labeled PCR Product}

Three PCR reactions from a single cDNA preparation were performed. Ten-microliter aliquots of the ${ }^{32}$ P-labeled PCR product were taken at 20,22, 24, 30, 35, and 40 cycles and applied to a $1 \%$ agarose (ME Agarose, FMC Bioproducts) gel. The DNA products were electrophoresed in $1 \mathrm{X}$ TBE buffer at $100 \mathrm{~V}$ for $45 \mathrm{~min}$. The gels were washed $2 \times 15 \mathrm{~min}$ in $0.5 \mathrm{M}$ $\mathrm{NaOH}$ and $1.5 \mathrm{M} \mathrm{NaCl}, 2 \times 15 \mathrm{~min}$ in 0.5 $\mathrm{M}$ Tris, and $1.5 \mathrm{M} \mathrm{NaCl}(\mathrm{pH} 7.4), 1 \times 5 \mathrm{~min}$ in $2 \times$ SSC, and transferred to a Nytran filter (Micron Separation, Inc.) overnight. The filters were UV-cross-linked (UV Stratalinker, Stratagene) and then autoradiographed using Kodak x-omat film (XAR-2). The film was developed after various exposure times and then analyzed by scanning densitometry using the Collage Analyst System (Fotodyne).

\section{Quantitative Analysis of the Fluorescein-labeled PCR Product with ELOSA}

A standard curve was determined for both the human and rat actin-synthesized 80-mer oligonucleotides with appropriate dilutions. Ten-microliter aliquots of three separate fluoresceinlabeled PCR products from a single cDNA preparation were taken at 20, 22, $24,30,35$, and 40 cycles of PCR amplification and diluted to various dilutions with deionized, double-distilled water to a total volume of $20 \mu \mathrm{l}$. The PCR product was heat denatured for $10 \mathrm{~min}$ at $100^{\circ} \mathrm{C}$ and then cooled at $4^{\circ} \mathrm{C}$. Twenty microliters of the standard dilutions, or denatured sample, was aliquoted to the streptavidin-coated microtiter plate wells (DuPont). One hundred microliters of hybridization buffer (10\% formamide, $6 \times$ SSC, $1.2 \%$ Triton $\mathrm{X}-100,0.12 \%$ BSA) containing $10 \mathrm{~nm}$ of biotin-labeled captured probe [and fluorescein-labeled reporter probe ( $5 \mathrm{~nm}$ ) for the standard only] was added to each well and incubated at $37^{\circ} \mathrm{C}$ for $1 \mathrm{hr}$. The plate was washed six times with $1 \times$ DuPont plate wash buffer (DuPont). One hundred microliters of antifluorescein horseradish peroxidase (HRP) conjugate (1:200)(DuPont) in antifluorescein diluent buffer (PBS, 2\% Tween, 5\% FCS, $0.2 \%$ casein) was added to the wells and incubated at room temperature for $15 \mathrm{~min}$. The wells were washed six more times and $100 \mu \mathrm{l}$ of trimethylbenzidene blue (TMB) substrate (ScyTek Laboratories) was added and incubated for $60 \mathrm{~min}$ in the dark at room temperature. The reaction was stopped with TMB stop solution (ScyTek Laboratories), and substrate development was read on a microtiter plate reader (Bio-Tek automated microplate reader, model EL340) at an absorbance of $450-630 \mathrm{~nm} .^{(15,16)}$ A standard curve was generated for each PCR reaction by using a serial dilution of a synthesized single-stranded DNA oligonucleotide identical in sequence to the target DNA. The concentration of the synthetic DNA was determined spectrophotometrically. By comparing the absorbance obtained from a sample containing an unknown 
amount of DNA with that obtained from the standard, the concentration of the target DNA can be determined.

\section{RESULTS}

B-Actin mRNA was detected in human liver and rat ventricle using the ${ }^{32} \mathrm{P}$-labeled PCR/Southern blot technique or the FAF-ELOSA technique. Figure 2 shows a representative PCR amplification of human liver $\beta$-actin cDNA. With both techniques, the amplification curves show logarithmic increases in product until a plateau phase is reached at $\sim 24$ cycles (Fig. 2A,B). The signal with ELOSA could still be detected with a 1:64 dilution of the PCR product detected with ${ }^{32} \mathrm{P}$ (Fig. 2B).

Relative quantitation of the ${ }^{32} \mathrm{P}$ endlabeled PCR product is possible, i.e., relative difference in the amount of target DNA is quantitated rather than a determination of femtomole concentration. In contrast, direct quantitation of the fluoresceinated PCR product was accomplished by (1) identifying the cycle number at which logarithmic increases were occurring (Fig. 2B), (2) performing a $1: 2$ dilution series with the PCR product at this cycle number, and analyzing absorbance readings at three points of signal linearity (Fig. 3A), (3) comparing these

A

B

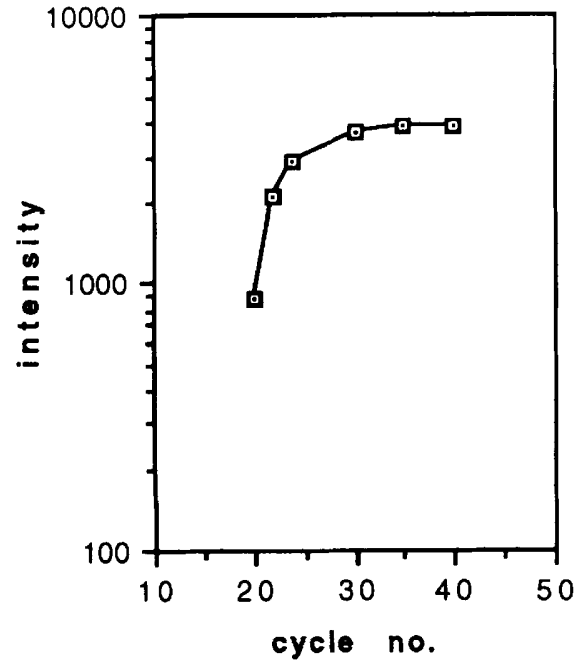

A

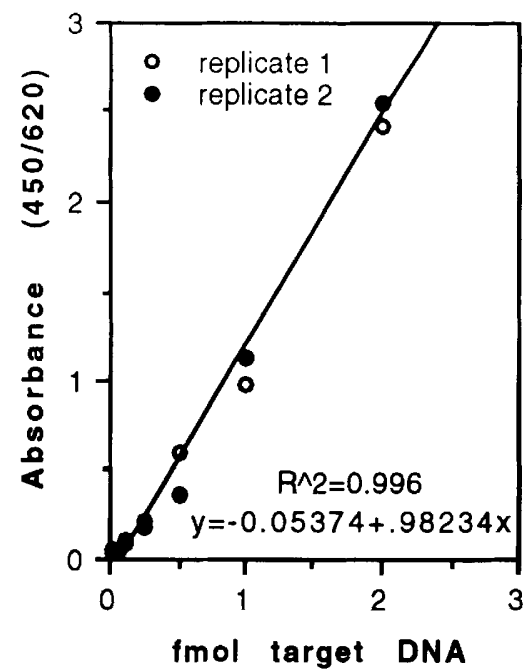

$\mathrm{B}$

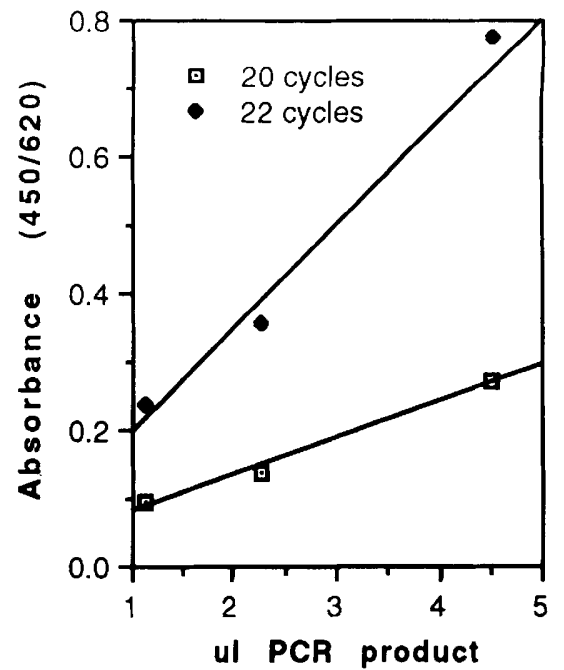

FIGURE 3 Quantitation of human actin PCR product. (A) Standard curve for human actin. A sensitivity of 0.05 fmole was achieved. A linear curve was obtained with a correlation coefficient of 0.996 . Two replicates are shown, indicating the small deviation among experiments. $(B)$ Following the observation that 20 and 22 cycles were in the exponential range of amplification, serial dilutions of the PCR products were made and FAF-ELOSA performed. The linearity of the quantitation is demonstrated. The number of femtomoles can then be calculated as indicated in Table 3.

absorbance readings with a standard curve with a known femtomole amount of 80-mer actin oligonucleotide standard (Fig. 3B), and (4) calculating the quantity

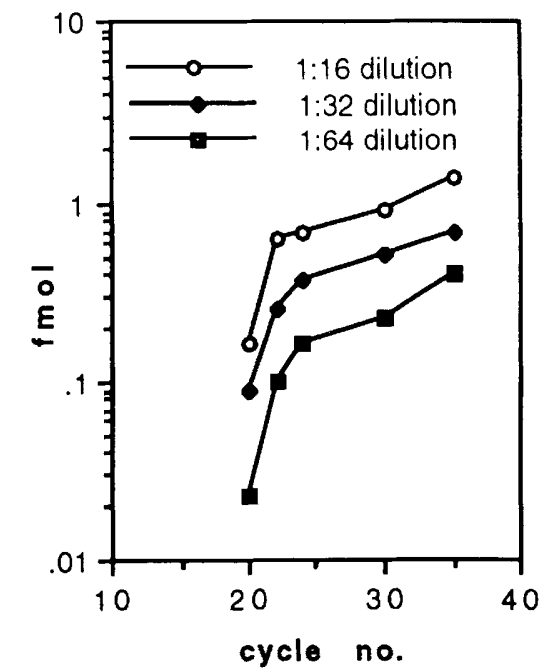

FICURE 2 Quantitation of human actin PCR product. (A) Typical results obtained for the ${ }^{32} \mathrm{P}$ labeled PCR/Southern blotting quantitation technique. The intensity value for each band as calculated as area under the curve was plotted versus cycle number. $(B)$ Results obtained for three separate dilutions of one PCR product by the FAF-ELOSA technique. Femtomoles of PCR-product as calculated from the standard curve are plotted versus cycle number. As shown, the plateau in PCR amplification occurred at a comparable point, as detected by both techniques.

as a mean and standard deviation of the three dilutions (Table 3). There was a $<15 \%$ standard deviation among these three dilution measures. We attribute this variation to unavoidable pipetting errors and to potential variations in the streptavidin coating of the microtiter plates. The FAF-ELOSA technique allows us to detect $<0.05$ fmole of actin PCR product.

In Table 4 , three rat actin PCR reactions from the same cDNA source were compared for coefficient of variation to determine any differences in variance when using the FAF-ELOSA or the ${ }^{32} \mathrm{P}$ labeled PCR/Southern blot technique. At 20 and 22 cycles, the variance among the three PCR reactions was similar with both the two assay techniques. This suggests that the FAF-ELOSA adds no greater variability to the differences observed among these three separate PCR reactions than was apparent with the ${ }^{32} \mathrm{P} /$ Southern blot technique.

The quantitation of PCR product by FAF-ELOSA from known amounts of cDNA is demonstrated in Table 5. With 400 and $40 \mathrm{ng}$ of human liver CDNA, we demonstrated that the absorbance readings of the PCR products at 22 and 24 cycles show the same 10:1 ratio as predicted from the ratio of starting cDNA 
TABLE 3 Human $\beta$-actin Amplification

\begin{tabular}{lcc}
\hline & $\begin{array}{l}\text { Absorbance at 450/620 } \\
\text { (calculated fmole) } \\
\text { 20 cycles }\end{array}$ & $\begin{array}{l}\text { Absorbance at 450/260 } \\
\text { (calculated fmole) } \\
\text { 22 cycles }\end{array}$ \\
\hline $4.5 \mu \mathrm{l}(1: 2$ dilution of PCR product) & $0.208(4.58)$ & $0.620(13.40)$ \\
$2.25 \mu \mathrm{l}(1: 4$ dilution of PCR product) & $0.099(4.28)$ & $0.280(12.10)$ \\
$1.13 \mu \mathrm{l}(1: 8$ dilution of PCR product) & $0.065(5.62)$ & $0.183(15.81)$ \\
fmole (mean \pm s.D.) & $4.83 \pm 0.70$ & $13.77 \pm 1.88$ \\
\hline
\end{tabular}

The data shown are the actual absorbance readings for each cycle, and in parentheses, the calculated number of total femtomoles per $100-\mu l$ reaction for both 20 and 22 cycles. The average deviation is $<15 \%$, mainly attributable to inaccuracy in pipetting microliter volumes.

material. Because the absorbance readings are on the linear range of the standard curve, the technique described in Figures 2 and 3 allows quantitation as a femtomole amount of PCR product. This accurate quantitation process required $<4 \mathrm{hr}$ from the moment of PCR amplification to the point of quantitation. The ${ }^{32} \mathrm{P}$ technique generally requires 2 days.

In Table 6, the quantitation of CYP2D6 and CYP2E1 mRNAs in a second human liver sample is used as an example of applying the FAF-ELOSA technique to specific targets of interest. The exponential range of amplification and linear range of absorbance for each $\mathrm{P} 450$ were determined by the same approach as described above for actin. Absorbance readings, calculated concentrations, and the ratio of P450 mRNA to actin mRNA at 22 cycles are given. Again, a 10-fold difference in starting cDNA template was reflected as $\sim 10$-fold difference in concentration of PCR product in the exponential range of amplification.

\section{DISCUSSION}

The ELOSA is a sensitive assay for quantitation of mRNA through PCR amplification of a known mRNA sequence. Specificity is achieved by primer selection and an internal capture probe. Multiple controls, such as the use of a standard sample, and amplification of either an internal or external control should be included to verify the reproducibility and accuracy of the assay. The FAFELOSA procedure can be performed within a relatively short period of time from the preparation of the PCR product with the use of the enzyme-linked immunosorbent assay (ELISA) format, a commonly used clinical laboratory technique.

Several strategies may be used in de- signing primers and probes for ELOSA. As a matter of clarity we use the term capture probe to identify biotin-labeled oligonucleotides designed to hybridize to the PCR product and attach to the streptavidin-coated well. The term reporter probe is used to identify fluorescein-labeled oligonucleotides designed to be added to the hybridization mixture to hybridize to the PCR product and attach to FAF antibody, and the term primer is used to identify any oligonucleotide (unlabeled or labeled with biotin or fluorescein) designed to be added to the PCR mixture to amplify and produce the PCR product (Fig. 1). Landgraf et al. incorporated a biotin primer and a fluorescein primer into their PCR mixture and amplified a PCR product that in and of itself attached to the streptavidin plate and attached to FAF. ${ }^{(11)}$ The advantage of this technique is the low cost of synthesizing multiple probes. The disadvantage of this approach is that excess biotin primer in the PCR mixture must be removed from the PCR product before the sample is added to the well as it will otherwise compete for avidin-binding sites with the biotin incorporated into the PCR product. Eron et al. ${ }^{(12)}$ used a sandwich assay, designing a capture probe and a reporter probe in addition to the two primers used for the PCR reaction. However, this approach has a disadvantage of higher costs of synthesizing probes and primers. In this paper we incorporated a fluorescein primer into our PCR product and designed an internal capture probe separate from the $5^{\prime}$ unlabeled primer sequence. This capture probe was designed within $20 \mathrm{bp}$ of the 3' fluorescein primer incorporated into the PCR product. This has two theoretical advantages. First, we minimize costs and time without requiring a primer separation step. Second, this strategy con- fers another level of specificity, as any nonspecific PCR product that might have homology with two $20 \mathrm{bp}$, that are $\sim 200$ bp apart is less likely to have homology with a third $20 \mathrm{bp}$ that is only 20 bp from the $3^{\prime}$ fluorescein-labeled primer.

Despite the advantages of the ELOSA assay over the ${ }^{32} \mathrm{P}$ technique, the need for standardization remains paramount. The valid concerns about variations in the RT step and PCR reaction variability from tube to tube requires that internal standards be run. Furthermore, just as ${ }^{32} \mathrm{P}$ labeling standardization is necessary across experiments, so too does ELOSA require standardization across microtiter plates. It is important to determine the linear range of amplification for each target mRNA of interest. Differences in denaturation and reannealing, hybridization, antibody binding, and color reaction must all be considered if quantitation from plate to plate or day to day is to be compared. The simultaneous running of a known cDNA sample across all plates over time is recommended to allow for correction of any plate-to-plate variation that might occur. The use of a synthesized oligonucleotide standard for each PCR product should also be considered to further verify that observed changes in experimental samples are valid. Additional controls for fluctuations in the efficiency of the RT step should be performed, for example, the coamplification of a relatively invariant mRNA or amplification of a known amount of an unrelated template RNA with the target RNA. A synthetic internal standard that uses the same target primer sequences but yields a product of different size has also been utilized as a

TABLE 4 Rat $\beta$-actin Amplification

\begin{tabular}{lll}
\hline $\begin{array}{l}\text { Cycle } \\
\text { number }\end{array}$ & $\begin{array}{l}\text { FAF-ELOSA } \\
\text { coefficient of } \\
\text { variation }\end{array}$ & $\begin{array}{l}\text { 32P-labeled } \\
\text { PCR/Southern } \\
\text { blot coefficient } \\
\text { variation }\end{array}$ \\
\hline 20 & 24.1 & 16.4 \\
22 & 18.1 & 20.7 \\
\hline
\end{tabular}

From the same cDNA preparation, three separate PCR reactions for each quantitative analysis technique were performed with aliquots taken during the exponential phase of amplification at 20 and 22 cycles. The coefficient of variations for the FAF-ELOSA assay and the ${ }^{32} \mathrm{P}$-labeled PCR/Southern blot results were similar. 
TABLE 5 Quantitative Estimate of Actin mRNA Concentration by FAF-ELOSA

\begin{tabular}{llccc}
\hline & \multicolumn{4}{c}{ Cycle number } \\
\cline { 2 - 5 } cDNA sample (ng) & 20 & 22 & 24 & 30 \\
\hline 40 & 0.003 & 0.012 & 0.033 & 0.67 \\
400 & 0.025 & 0.132 & 0.339 & 0.897 \\
Ratio & 8.3 & 11.0 & 10.3 & 1.4 \\
\hline
\end{tabular}

cDNA ( 40 and $400 \mathrm{ng}$ ) from a second human liver sample was PCR amplified and analyzed by the FAF-ELOSA technique. The exponential range of amplification is similar for both starting amounts. At the logarithmic phase of amplification, there was an $\sim 10: 1$ ratio of absorbance readings. Using a standard curve, the calculated femtomole concentration from $400 \mathrm{ng}$ starting template was 1.43 fmole/total PCR product at 22 cycles and 3.62 fmoles/total PCR product at 24 cycles.

RT control. ${ }^{(2)}$ There are, however, several limitations to these approaches as well, including the requirement that both products are amplified with the same efficiency and kinetics and potential differences in RNA purity and degradation rates are accounted for. ${ }^{(17)}$

In conclusion, ELOSA is a sensitive assay for the quantitation of mRNA and has no disadvantages when compared with the ${ }^{32}$ P-labeled PCR/Southern blotting technique. The clear advantages of the ELOSA technique are that (1) it can be performed in a relatively short time, (2) it is nonradiometric, and (3) it can be quantified to a known standard. The ELOSA assay is therefore preferred for mRNA quantitation in mass samples for

TABLE 6 Human CYP2D6 and CYP2E1 Amplification

\begin{tabular}{lcc}
\hline \multicolumn{2}{c}{ CYP2D6 } \\
\hline $\begin{array}{l}\text { cDNA } \\
\text { (ng) }\end{array}$ & $\begin{array}{l}\text { absorbance } \\
\text { reading }\end{array}$ & $\begin{array}{l}\text { calculated } \\
\text { amole/total } \\
\text { PCR product }\end{array}$ \\
\hline 40 & 0.065 & 0.54 \\
400 & 0.518 & 4.56 \\
& CYP2E1 & \\
\hline cDNA & absorbance & calculated \\
(ng) & reading & PCR product \\
\hline 40 & 0.024 & 0.40 \\
400 & 0.283 & 4.68 \\
\hline
\end{tabular}

A 10 -fold difference in starting cDNA template was reflected as an $\sim 10$-fold difference in concentration of PCR product after $22 \mathrm{cy}$ cles, which is in the exponential range of amplification for CYP2D6, CYP2E1, and actin. For $400 \mathrm{ng}$ of starting cDNA template, the calculated ratios for $\mathrm{P} 450$ expression in this human liver were 5.7 amoles CYP2D6/fmole actin and 5.9 amoles CYP2E1/fmole actin. clinical tests. Future studies will determine its accuracy, reproducibility, and sensitivity in this setting.

\section{REFERENCES}

1. Saiki, R.K., S. Scharf, F. Faloona, K.B. Mullis, G.T. Horn, H.A. Erlich, and N. Arnheim. 1985. Enzymatic amplification of beta-globin genomic sequences and restriction site analysis for diagnosis of sickle cell anemia. Science 230: 13501354.

2. Wang, A.M., M.V. Doyle, and D.F. Mark. 1989. Quantitation of mRNA by the polymerase chain reaction. Proc. Natl. Acad. Sci. 86: 9717-9721.

3. Noonan, K.E., C. Beck, T.A. Holzmayer, J.E. Chin, J.S. Wunder, I.L. Andrulis, A.F. Gazdar, C.L. Willman, B. Griffith, D.D. Von Hoff, and I.B. Roninson. 1990. Quantitative analysis of MDR1 (multidrug resistance) gene expression in human tumors by polymerase chain reaction. Proc. Natl. Acad. Sci. 87: 7160-7164.

4. Murphy, L.D., C.E. Herzog, J.B. Rudick, A.T. Fojo, and S.E. Bates. 1990. Use of the polymerase chain reaction in the quantitation of mdr-1 gene expression. Biochemistry 29: 10351-10356. and T.J. White, eds. PCR protocols: A guide to methods and applications. 1990. Academic Press, San Diego, CA.

6. Kolls, J., P. Deininger, J.C. Cohen, and J. Larson. 1993. cDNA equalization for reverse transcription-polymerase chain reaction quantitation. Anal. Biochem. 208: 264-269.

7. Syvanen, A.C., M. Bengstrom, C.H. Levenson, and H.A. Erlich. 1989. Quantitation of polymerase chain reaction products by affinity-based hybrid collection. Proc. Natl. Acad. Sci. 86: 6230-6234.

8. Inouye, S. and R. Hondo. 1990. Microplate hybridization of amplified viral DNA segment. J. Clin. Microbiol. 128: $1469-1472$.

9. Keller, G.H., D.-P. Huang, J.W.-K. Shih,
5. Innis, M.A., D.H. Gelfand, J.J. Sninsky, and M.M. Manak. 1990. Detection of hepatitis $B$ virus DNA in serum by polymerase chain reaction amplification and microtiter sandwich hybridization. J. Clin. Microbiol. 28: 1411-1416.

10. Keller, G.H., D.-P. Huang, and M.M. Manak. 1991. Detection of human immunodeficiency virus type 1 DNA by polymerase chain reaction amplification and capture hybridization in microtiter wells. J. Clin. Microbiol. 29: 638-641.

11. Landgraf, A., B. Reckmann, and A. Pingoud. 1991. Direct analysis of polymerase chain reaction products using enzymelinked immunosorbent assay techniques. Anal. Biochem. 198: 86-91.

12. Eron, J.J., P. Gorczyca, J.C. Kaplan, and R.T. D'Aquila. 1992. Susceptibility testing by polymerase chain reaction DNA quantitation: A method to measure drug resistance of human immunodeficiency virus type 1 isolates. Proc. Natl. Acad. Sci. 89: 3241-3245.

13. Park, O.-K. and K.E. Mayo. 1991. Transient expression of progesterone receptor messenger RNA in ovarian granulosa cells after the preovulatory luteinizing hormone surge. Mol. Endocrinol. 5: 967-978.

14. Ausubel, F.M., R. Brent, R.E. Kingston, D.D. Moore, J.G. Seidman, J.A. Smith, and K. Struhl, eds. Current protocols in molecular biology. 1991. Greene Publishing Association/Wiley Interscience, New York.

15. Conway, B., L.J. Bechtel, K.A. Adler, R.T. D'Aquila, J.C. Kaplan, and M.S. Hirsch. 1992. Comparison of spot-blot and microtitre plate methods for the detection of HIV-1 PCR products. Mol. Cell. Probes 6: 245-249.

16. Adler, K. 1993. Pers. comm.

17. Ferre, F. 1992. Quantitative or semi-quantitative PCR: Reality versus myth. PCR Methods Applic. 2: 1-9.

Received December 2, 1993; accepted in revised form February 1, 1994. 


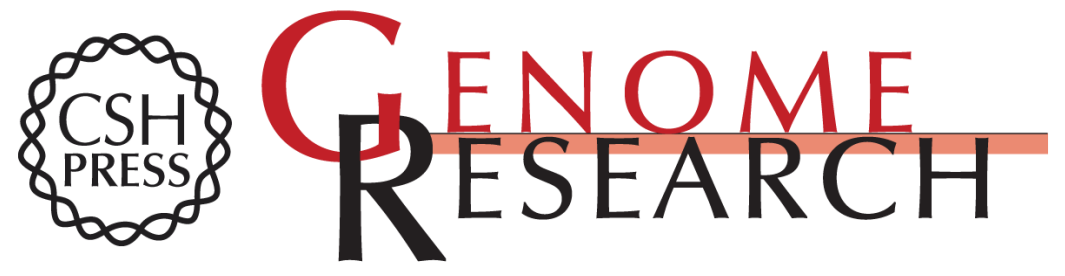

\title{
Comparison of the enzyme-linked oligonucleotide sorbent assay to the 32P-labeled PCR/Southern blotting technique in quantitative analysis of human and rat mRNA.
}

\author{
J A Carcillo, A Parise and M Romkes-Sparks
}

Genome Res. 1994 3: 292-297
References This article cites 14 articles, 7 of which can be accessed free at:
http://genome.cshlp.org/content/3/5/292.full.html\#ref-list-1

\section{License}

Email Alerting

Service Receive free email alerts when new articles cite this article - sign up in the box at the
top right corner of the article or click here.

\section{Affordable, Accurate Sequencing.}

